\title{
MENGEMBANGKAN MUTU DAN PENDAMPINGAN INOVASI PRODUK DODOL DI JASINGA TENJO JAWA BARAT
}

\author{
Nur Hidayah $^{1}$ dan Rodhiah ${ }^{2}$ \\ ${ }^{1}$ Fakultas Ekonomi, Universitas Tarumanagara Jakarta \\ Email: nurida@fe.untar.ac.id \\ ${ }^{2}$ Fakultas Ekonomi, Universitas Tarumanagara Jakarta
}

\begin{abstract}
Abstrak--Kegiatan PKM bertujuan untuk meningkatkan mutu yang dihasilkan dan melakukan inovasi atas produk dodol yang terdapat di Jasinga Tenjo Jawa Barat. Alasan pemilihan kegiatan ini didasarkan pada observasi awal pada mitra pemilik usaha dodol yang memiliki keterbatasan dalam mengembangkan usaha dodol. Padahal dodol merupakan makanan khas yang perlu terus dilestarikan. Disamping itu ciri khas daerah ini banyak pengrajin dodol, namun kurang diketahui keberadaannya, selain itu kurang dikenal oleh masyarakat luar daerah Tenjo. Metode yang digunakan berupa forum discusion group dengan pemilik usaha sebagai mitra kegiatan PKM, melakukan pelatihan manajemen mutu/kualitas produk yang dihasilkan, FGD menyusun desain inovasi produk yang sebaiknya dilakukan guna meningkatkan daya saing produk yang dijual. Selanjutnya melakukan pendampingan pengadaan produk yang lebih inovatif dan memiliki kreasi yang lebih beragam. Target yang diharapkan mencapai luaran, yaitu: 1). Model pengenalan manajemen mutu atas produk mitra. 2). Inovasi produk baik dalam bentuk ukuran, kemasan dan rasa. Berdasarkan output tesebut diharapkan mampu merubah cara pikir, kesadaran dan pemahaman pemilik usaha tentang pentingnya manajemen mutu dan inovasi produk yang lebih kreatif. Dengan demikian akan meningkatkan kualitas dan variasi produk yang lebih beragam. Sehingga diharapkan pendapatan pemilik usaha akan lebih meningkat, dan usaha menjadi lebih berkembang.
\end{abstract}

Kata kunci: Bentuk; Inovasi rasa; Kemasan; Manajemen mutu; UKM Dodol.

\section{Pendahuluan}

Upaya mengembangkan wirausaha di Indonesia telah lama dilakukan berbagai pihak, baik pemerintah maupun swasta. Karena wirausaha merupakan sumber potensi ekonomi yang sangatlah besar. Zimmerer (2008) mengemukakan kewirausahaan adalah hasil dari satu disiplin proses sistematis penerapan kreativitas dan inovasi dalam memenuhi kebutuhan serta peluang di pasar. Kreativitas adalah inisiatif terhadap suatu produk atau proses yang bermanfaat, tepat, dan bernilai, terhadap suatu tuas yang lebih bersiat heuristic yaitu sesuatu yang merupakan pedoman, petunjuk, atau panduan yang tidak lengkap yang akan menuntun kita untuk mengerti, mempelajari, atau menemukan sesuatu yang baru (Ernani Hadiyati,2010). Larsen P and Lewis A,(2007) menyatakan bahwa salah satu karakter yang sangat penting dari wirausahawa adalah kemampuannya berinovasi. Tanpa adanya inovasi perusahaan tidak akan bertahan lama. Berdasarakan penelitian terdahulu menurut Krisdayanti,2010 bahwa proses kreativitas dan inovasi hanya dilakukan oleh orang-orang yang memilki jiwa dan sikap kewirausahaan yaitu orang yang percaya diri (yakin, optimis, dan penuh komitmen) berinisiatif ( energik dan percaya diri ) memilki motif berprestasi (berorientasi hasil dan berwawasan kedepan) dan berani mengambil resiko dengan penuh perhitungan (karena itu suka tantangan). Konsep kewirausahaan, penting dalam rangka pengembangan UMKM, karena kewirausahaan merupakan karakteristik kemanusiaan yang berfungsi besar dalam mengelola suatu bisnis, selain itu pengusaha yang memiliki jiwa kewirausahaan akan memperlihatkan sifat pembaharuan yang dinamis, inovatif dan adaptif terhadap perubahan kemajuan ilmu pengetahuan dan tehnologi (Ernani Hadiyati,2010). wirausahawan yang selalu berinovasi dapat dikatakan sebagai sebagai seorang wirausahwan yang inovatif. Seseorang yang inovatif akan selalu berupaya melakukan perbaikan, menyajikan sesuatu yang baru/unik yang berbeda dengan yang sudah ada. Inovatif juga merupakan sikap penting bagi 
yang hendaknya dimiliki oleh seorang wirausahawan. Dalam inovasi dapat diciptakan nilai tambah, baik pada organisasi, pemegang saham, maupun masyarakat luas.

Masalah dalam PKM ini meliputi inovasi yang perlu dilakukan oleh UKM. Dodol yang terdapat di Jasinga Tenjo Jawa Barat. Alasan utama mengapa kegiatan ini difokuskan pada usaha dodol, karena faktor berikut ini: 1.Sebagai usaha peningkatan ketahanan ekonomi masyarakat tingkat bawah. Usaha perseorangan ini sebagai peluang untuk mencapai kemandirian ekonomi pada kelompok masyarakat tersebut, 2.Sebagai upaya meningkatkan pemberdayaan rumahan di bidang ekonomi. Kebanyakan usaha rumahan yang memiliki latarbelakang pendidikan relatif rendah, 3.dodol yang terbuat dari bahan baku ketan adalah makanan khas masyarakat Indonesia harus terus ditingkankan inovasi dan kreatifitasnya 4. Sebagai upaya untuk melestarikan warisan budaya bangsa, sejak zaman dahulu masayakat telah membuat dodol.

Mitra yang dijadikan tempat kegiatan merupakan usaha kecil bergerak dalam bidang makanan dodol. Merupakan usaha yang baru berdiri selama kurang lebih 15 tahun. Dalam menjalankan usaha, menghadapai kendala atau kesulitan berkembang, di samping itu mereka belum menggunakan peralatan yang lebih modern dan memberikan jaminan kualitas yang lebih baik. Bagi usaha yang baru berdiri ini, masih banyaknya keterbatasan yang dimilki mitra. Dengan modal yang terbatas, mitra sebagai pemilik usaha tidak mempunyai variasi produk yang beragam, baik dari segi ukuran, rasa maupun kemasan yang lebih baik. Selama ini produk yang dijual hanya meliputi satu macam ukuran bulat sekitar $5 \mathrm{~cm}$ dan memancang sekitar 110 sampi $20 \mathrm{~cm}$ dan produk dikemas dengan plasik biasa dengan merek menggunakan kertas cel seperti Gambar 1.

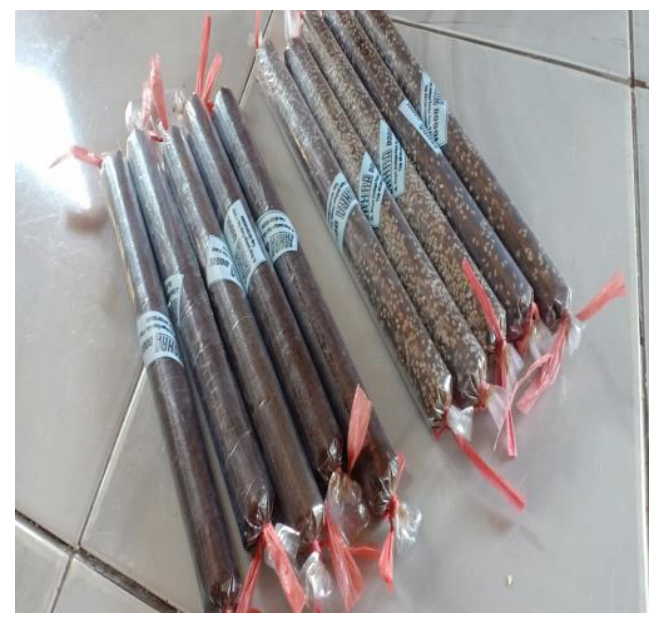

Gambar 1. Produk Dodol

Untuk itu Tim PKM yang memilki kemampuan IPTEKs tentang manajemen mutu maupun tentang inovasi produk berkeinginan mendorong pengembangan usaha mitra. Sehingga dapat menjadi suatu usaha yang lebih inovatif.

\section{Permasalahan Mitra}

Perkembangan usaha mitra masih cukup memprihatinkan, selayaknya dirasakan oleh semua pihak. Jika kondisi tersebut dibiarkan, maka lambat laun bisnis ini tidak akan bertahan dalam waktu yang lama. Ditambah lagi banyak nya pesaing yang ada disekitar mitra juga membuka usaha dodol cukup banyak. Mitra tidak hanya menghadapi kondisi pesaing besar tetapi juga pesaing kecil.

Terdapat beberapa persoalan yang dihadapi mitra usaha dodol maka yang menjadi prioritas permasalahan dapat dikelompokkan: Bagaimana pembekalan cara manajemen kualitas kepada 
mitra dodol di Tenjo;Bagaimana cara mensosialisasikan manajemen kualitas kepada mitra usaha dodol di Tenjo ;Belum tersedianya produk dodol yang lebih berinovasi, baik dari segi ukuran, rasa dan kemasan; Terkait dengan permasalashan ke-3. Maka persoalan khusus terkait dengan bagaimana mengembangkan inovasi mitra dalam mengemas produk yang lebih ber inovatif.

\section{METODE PELAKSANAAN}

Metode yang ditawarkan dalam mengatasi prtmasahan mitra adalah sosialisasi, dan pendampingan.

Kegiatan sosialisasi dilakukan untuk memberikan pembekalan terhadap pemahaman tentang pengetahuan dalam manajemen mutu, inovasi produk yang meliputi arti dari mutu, pentingmya menjaga mutu, proses mutu, mulai dari input-proses- output. Arti inovasi, pentingnya inovasi produk, kegiatan inovasi, baik dari rasa, ukuran dan kemasan. Terdapat beberapa langkah yang perlu dilakukan.

a. Tim PKM sebagai tutor menghubungi pihak terkait, yaitu pemilik usaha untuk minta ijin melakukan sosialisasi.

b. Tim PKM sebagi tutor berkoordinasi dengan pemilik agar dapat memberikan jadwal untuk melakukan kegiatan sosialisasi.

c. Tim PKM sebagai tutor menyampaikan materi sosialisasi melalui ceramah, diskusi, dan tanya jawab. sosialisasi tentang manajemen usaha dan kualitas

d. Tutor mejelaskan tentang apa yang harus dilakukan pemilik atau pimpinan usaha dalam menjalankan usaha dodol secara lebih terencana dan teratur, bagaimana mengkoordinir karyawan secara lebih baik serta melakukan evaluasi dari hasil usaha yang akan dilakukan. Contoh: Tutor menjelaskan tentang arti dari manajemen mutu dan inovasi .

e. Pemilik usaha mendengarkan dan memberikan respon pada tim PKM atas materi sosialisasi.

Kegiatan pendampingan dilakukan melalui mendesain ukuran, rasa dan kemasan produk dodol yang disesuaikan dengan variasi produk yang akan dijual. Langkah-langkah kegiatan pendampingan pembuatan kemasan adalah sebagai berikut.

a. Tim membuat mengecek produk yang dibuat

b. Tim melakukan pengukuran jumlah dodol yang akan dimasukkan dalam kemasan.

c. Tim mendatangi mempelajari beberapa alternatif logo desian dan alternatif bahan kemasan.

d. Tim melakukan proses pembuatan logo, desain, rasa yang diingkan

e. Tim menyampaikan pilihan beberapa logo desain dan rasa kepada pemilik

f. Tim menyuruh pemilik memutuskan pilihan sebelum proses cetak

g. Tim melakukan perjanjian dengan percetakan untuk proses percetakan kemasan

h. Tim melakukan pendampingan pada pengrajin untuk mendatangin tempat cetak desain

i. Tim beserta pemilik menunggu proses cetak

j. Tim menyerahkan kemasan yang siap pakai kepada pemilik usaha

\section{HASIL DAN Pembahasan}

\section{Profil Usaha Dodol}

Pemilik usaha bernama ibu Ade. Lokasi usaha menggunakan tempat tinggal sendiri yang terdapat di Kampung Maribaya Desa Panggaur Kecamatan Jasinga Bogor. Usaha dodol dilakukan oleh ibu Ade sendiri yang dibantu oleh beberapa karyawan. Ibu Ade menjalankan usaha sejak tahun 2016 meneruskan usaha orang tuanya.. Mengingat orang tua bu Ade sudah sudah berusia lanjut, sehingga usaha dodol dilanjutkan oleh putrinya bernama bu Ade. Orang tua bu Ade 
merupakan orang pertama di tenjo yang membuat usaha dodol sebelum tahun 2000. Awalnya dodol yang dibuat tidak diberi nama merek dan tidak ada pesaing, namun setelah usaha berjalan selama 19 tahun mulai muncul pesaing pesaing baru. Saat ini yang menggantikan usaha adalah putrinya bu Ade. Bu Ade baru memulai usaha 3 tahun. Kemudian dodol diberi nama merek Zahra. Yang diambil dari nama putrinya bu Ade.

Prosses produksi dodol dilakukan di rumah tempat tinggal, dibagian samping dan belakang, dibagun tempat produksi yang dilengkapi dengan alat alat yang masih sederhana dan sangat tradisional. Kondisi tempat produksi dapat dilihat pada Gambar 2.
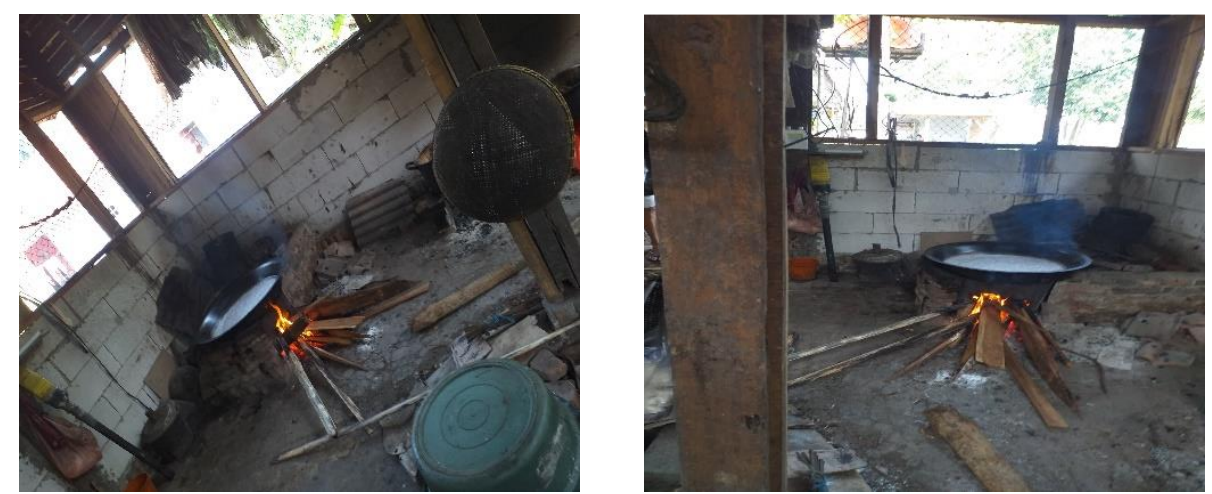

Gambar 2. Tempat Produksi Usaha Dodol

Produk dodol yang dihasilkan meliputi dodol bulat panjang sekitar $10 \mathrm{~cm}$, dibungkus dengan plastik tipis dengan dua rasa yaitu rasa original yang dibuat secara polos dan rasa yang dicampur dengan wijen . Pada saat kondisi hari hari biasa dapat memproduksi 10 sampai $30 \mathrm{~kg}$. Namun pada kondisi di saat hari lebaran produksi bisa mencapai 80 sampi $120 \mathrm{~kg}$. Suasana tempat produksi produk dan hasil produk yang dihasilkan terlihat pada Gambar 3.
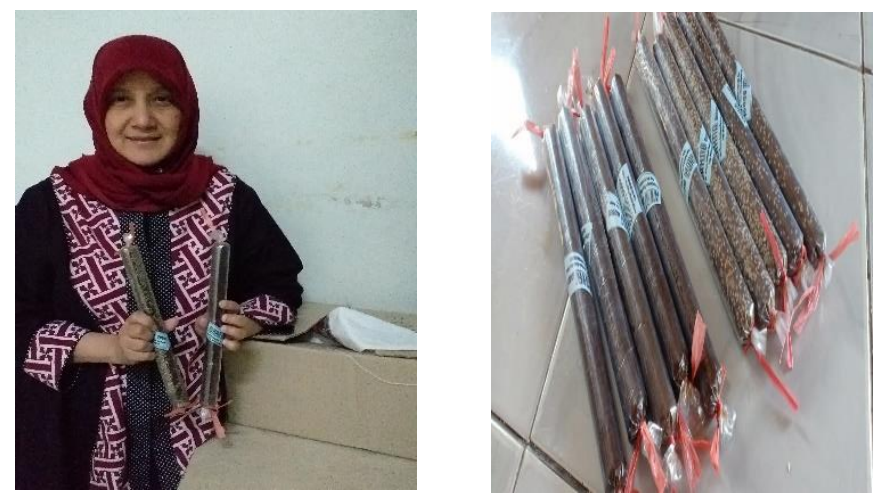

Gambar 3. Produk Dodol Yang Dihasilkan

\section{Pelatihan Manajemen Mutu}

Proses FDG dilakukan juga pada pembuatan model pelatihan manajemen mutu usaha dodol. Usaha ini bersifat perorangan sehingga pengenalan manajemen mutu diaplikasikan secara sederhana terkait dengan pengenalan mutu bahan baku, mutu saat proses produksi dan terakhir mutu saat produk siap untuk dipasarkan. Beberapa langkah dalam manajemen mutu yang perlu disosialisasikan saat pelatihan:

Langkah Pertama mendesain Model Manajemen Mutu Usaha Dodol Zahra melalui rantai pasokan usaha dodol . Menurut Sammers (2009) hlm. 222: 
"A supply chain is the network of organizations involved in the movement of materials, informations, and money as raw material flow their source through production until they are delivered as finished product or service to the final customer. "

Jika rantai pasokan disinergikan dengan manajemen rantai pasok, maka manajemen rantai pasokan dikembangkan sebagai rangkaian proses mulai bahan baku s/d distribusi output bagi konsumen. Konsep rantai nilai sebagai bukti tanggung jawab kepada konsumen dan umpan balik sebagai proses perbaikan berkelanjutan. Pengembangan rantai pasokan dijabarkan ;.

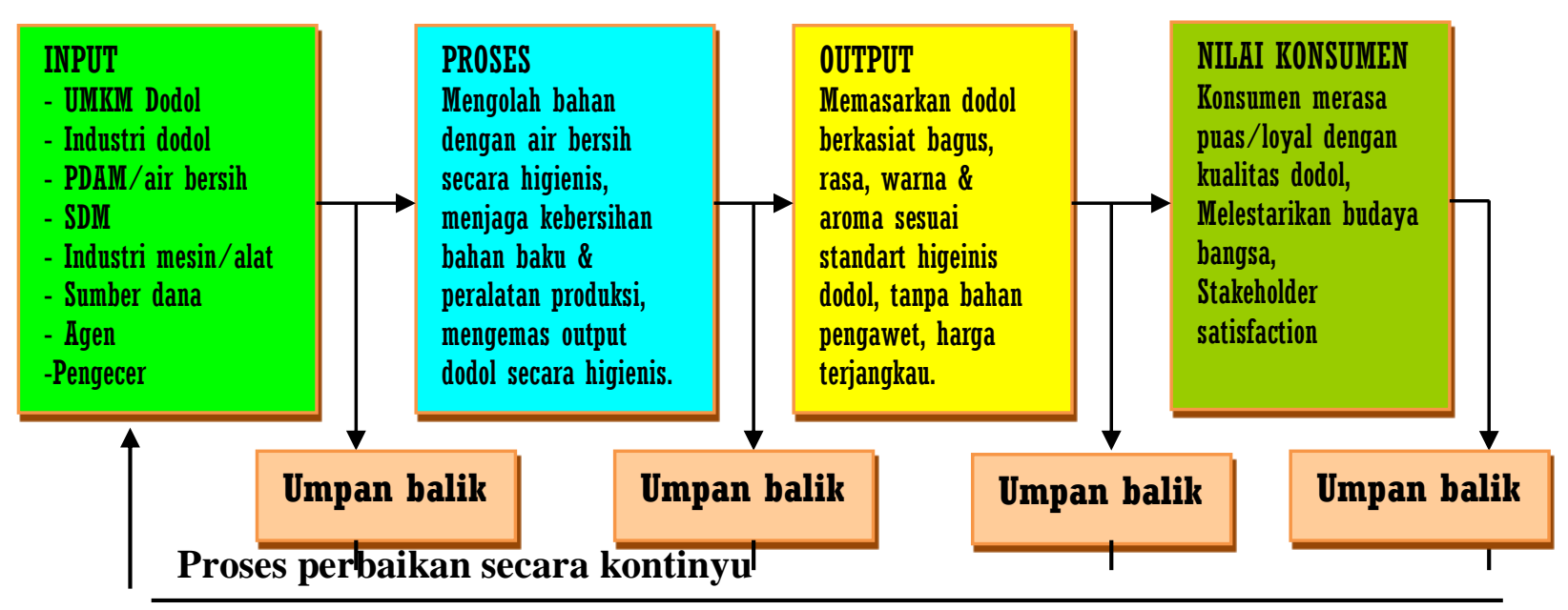

Gambar 4. Manajemen Rantai Pasokan Dodol

Langkah Kedua: Berdasarkan Bagan tersebut serta mengacu the Deming's cycle dikembangkan menjadi siklus kualitas Dalam the Deming's cycle dijelaskan siklus P-D-C-A meliputi: Planning the product, Produce the product, Check the product make sure with the plan, Market the product, and Analysis the product is received in marketplace. (Goetsch and Davis; 1997) Prinsip siklus kualitas dodol sebagai berikut: 1. Memperhatikan kualitas \& keaslian bahan baku (Input). 2 . Memperhatikan kualitas \& kebersihan selama pembuatan dodol (Proses). 3. Menghasilkan output \& layanan berkualitas kepada pelanggan dodol (Output). 4. Memperhatikan kualitas lingkungan (Nilai konsumen). 5.. Menjaga hubungan dengan lingkungan (Environment).. Siklus harus dikelola oleh komunitas secara berkelanjutan.

Langkah Ketiga: Berdasarkan Bagan tersebut dibreakdown menjadi Model Manajemen Mutu Usaha dodol. Adopsi unsur TQM pada Model tersebut yaitu: management commitment, leadership, information management, quality insurance, continous improvement, supplier relationship, quality supplier, employee empowerment \& involvement, management customer relationship, market \& customer knowledge, team work, scientific approach. (Khairul and Hayati; 2013, Hayati and Idris; 2013, Hoang et al; 2010,) Model msnajemen mutu usaha dodol terdiri dari 5 proses manajemen yaitu: 1. Input bahan baku. 2. Proses Pembuatan. 3. Penyajian Output. 4. Kualitas Pelayanan Konsumen. 5. Pelayanan \& Penjalinan Relasi Masyarakat. Dengan 
memperhatikan proses pada model tersebut semakin mengangkat image komunitas dodol dan kepercayaan konsumen. Pedagang tidak semata berorientasi pada keuntungan, tetapi bertanggung jawab terhadap nilai pelanggan. Implementasi sebagai rekayasa sosial membangun budaya kualitas pada home industri. Kemandirian menerapkan kualitas dodol akan meningkatkan daya saing usaha dodol secara berkelanjutan.

Pencapaian hasil penerapan Model manajemen mutu dodol berupa peningkatan daya saing usaha dodol Indiator nya berupa 1. Sales \& overall competitiveness (Ahmed \& Hasan; 2003). 2. Profit (Husain et al; 2001, Hayati et al; 2013). 3. Product/service quality \& supplyer performance (Brah et al; 2002). Sementara indikator daya tawar berdasarkan: 1. Image (Husain et al; 2001). 2. Employee behavoiur atau employee morale (Chong et al; 2001, Kibe \& Wanjau; 2014). 3. Society result (Tari et al; 2007). 4. Customer satisfaction \& impact on society (Fotopoulos et al; 2009). 5. Customer relation (Amurugam et al; 2008) Pencapaian kinerja kualitas usaha dodol: Pertama, Daya saing: pertumbuhan/volume penjualan, profit, kualitas produk/jasa, kualitas supplyer. Kedua, Daya tawar: Image masyarakat terhadap produk dodol, perilaku konsumen, dampak masyarakat/lingkungan, kepuasan pelanggan, hubungan pelanggan.

Kegiatan manajemen mutu yang meliputi langkah langkah di atas, dilakukan dalam upaya meningkatkan pengetahuan dan pembekalan bagi pemilik dan anggota keluarga serta membantu usaha dodol tersebut, dalam upaya melestarikan penjualan dodol di masa yang akan datang. Khusus untuk pengelolaan hasil usaha maka dapat dilihat Ibu Ade beserta keluarga dapata survive dan permintan terus meningkat. Peningkatan hasil ibu Ade dapat menghasilkan pendapatan dalam membantu suami dalam memenuhi kebutuhan keluarga.

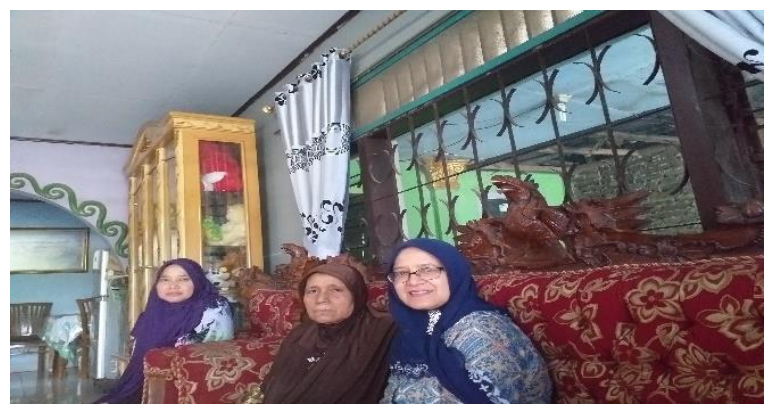

Gambar 5. Sosialisasi Manajemen Mutu

\section{Pendampingan Inovasi Produk Usaha Dodol}

Konsep inovasi yang dilakukan untuk usaha dodol agar dapat berbeda dari pesaing, tim mengajukan beberapa alternatif inovasi pada mitra tentang ukuran, bentuk dan kemasan dodol. Hasil dari inovasi tersebut akan dilanjutkan dengan proses uji coba penjualan. Adapun langkah langkah pendampingan ke mitra selama melakuklan proses inovasi meliputi:

1. Langkah pertama melakukan FGD kepada pemilik dan anggota keluarga lainnya untuk menentukan jenis dus yang akan digunakan, ukuran dan warna sera logo merek yang akan ditampilkan pada kemasan..

2. Melakukan penjajakan terhadap beberapa model desain melalui internet maupun observasi lapangan ke tempat yang menjual dodol.

3. Melakukan proses desain dengan melibatkan mahasiswa FSRD.

4. Setelah proses gambar dibuat di sosialisasikan kepada seluruh Tim untuk mendapatkan input kecocokan gambar yang sudah didesain.

Hasil desain tersebut adalah; 
5. Tim mendiskusikan gambar desain ke pimilik usaha dodol untuk mendapatkan persetujuan sebelum melalakukan proses pencetakan.

6. Tim mencari tempat dus, printing melalui internet, dan memesan dus yang akan dilanjutkan dengan proses printing

7. Tim mencari tempat sablon. Setelah diperoleh selanjutnya tim menyerahkan dus yang sudah dibeli diserahkan untuk proses sablon.

8. Tim mendaparkan hasil dus yang sudah disablon untuk diserahkan ke mitra.

Selanjutkan dodol dibuat sesuai ukuran dus yang sudah dibuat dimasukkan dalam kemasan yang sudah di berikan ke mitra .untuk selanjutnya dodol ibu Ade siap dipasarkan. Proses lenyerahan kemasan dilakukan oleh ketua Tim ke tempat mitra nampak pada Gambar 6.

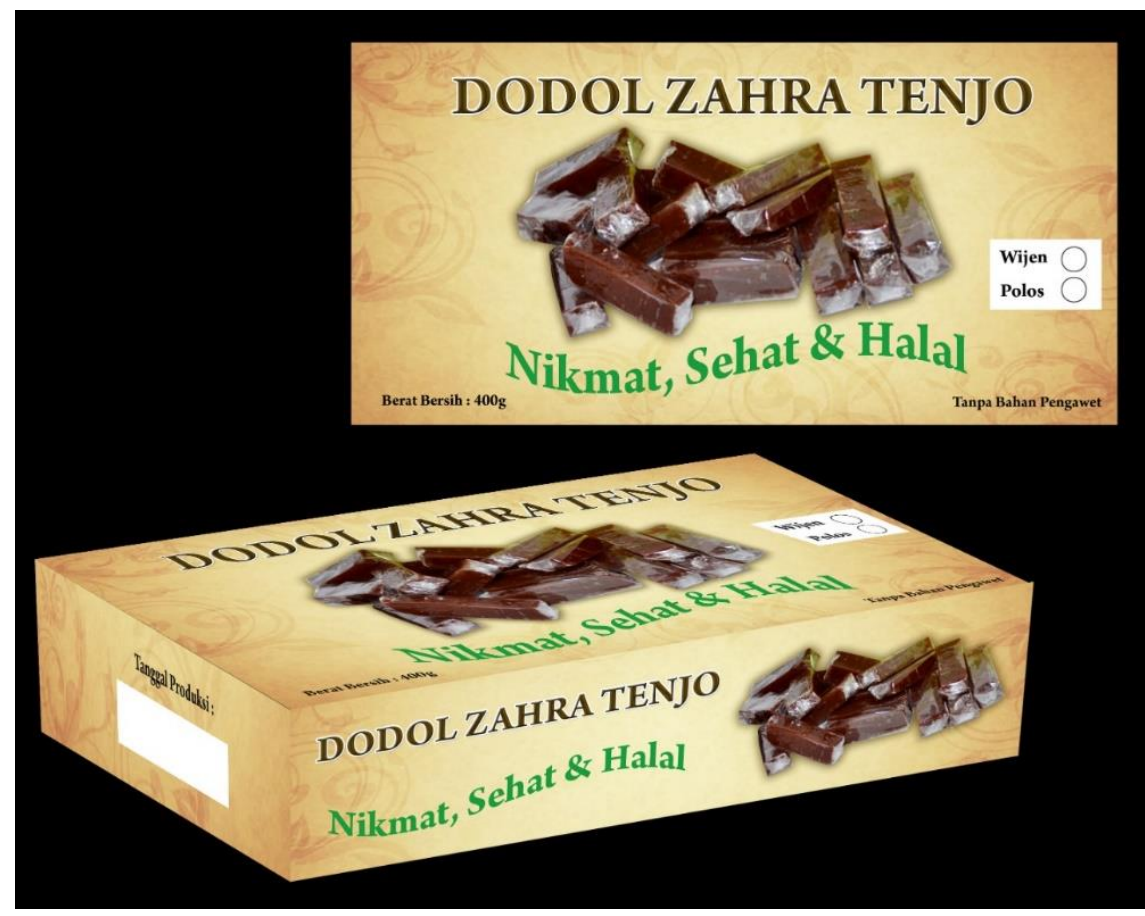

Gambar 6. Desain Kemasan Dodol Zahra

\section{KESIMPULAN DAN SARAN}

Berdasarkan pelaksanaan kegiatan yang sudah dilakukan maka dapat dibuat beberapa kesimpulan yaitu:

1. Materi manajemen mutu pada pemilik usaha dan keluarga yang terlibat menjalankan usaha dodol berjalan lancar dan telah dilakukan dengan baik.

2. Pelatihan dan sosialisasi terhadap manajemen mutu atas produk yang dihasilkan sesuai dengan kebutuhan pemilik usaha yang meliputi mutu dari input, proses dan output.

3. Membuat desain kemasan dengan melakukan perbandingan pada merek merek yang terdapat di berbagai media.

4. Melakukan inovasi produk dari yang hanya bulat panjang berujuran kurang lebih $50 \mathrm{~cm}$, menjadi ukuran yang lebih kecil sebesar ukuran telunjuk jari. 
5. Membuat kemasan yang di sablon sesuai dengan kategori yang diinginkan mitra. Dengan desain yang sudah mendapatkan persetujuan mitra.

6. Merubah kemasan mitra yang tadinya hanya plasik tipis polos menjadi dus yang yang diberi nama merek dodol zahra, Hal ini sesuai dengan keinginan inu Ade selaku pemilik usaha.

7. Menyerahkan kemasan yang sudah didesain dan diberi nama merek zahra sesuai keinginan mitra

Perbaikan ecara kontinyu usaha dodol terus dapat dulakukan anta lain dapat dikembangkan dalam kajian selanjutnya.

1. Proses pembinaan kontinuitas usaha, melalui pemetaan terhadap permasalahan usaha dodol.

2. Penerapan dan pengembangan pasar produk dodol melalui analisis pasar.

3. Melakukan kerja sama dengan pemilik bahan baku untuk mendapatkan kemudahan dalam mencari bahan baku utama.

\section{Ucapan Terima Kasih (Acknowledgement)}

Terima kasih penulis sampaikan kepada mitra kegiatan dan berbagai pihak yang terkait pada kegiatan PKM . Terima kasih juga pada DPPM untar yang telah memberikan pendaan sehingga kegiatan ini dapat di relialisasikan.

\section{REFERENSI}

Adair, J. (1996). Effective Innovation: How to Stay Ahead of the Competition. London: Pan Books Ltd.

Bagas Prakoso. 2005. Pengaruh Orientasi Pasar, Inovasi, dan Orientasi Pembelajaran mempengaruhi Kinerja Untuk Mencapai Keunggulan Bersaing. Jurnal Studi Manajemen \& Organisasi Vol.2 No.1 www.eprints.undip.ac.id/15063 diakses pada tanggal 20 April 2015 pukul 00.15 WIB

De Jong, J. (2007). Dissertation: Individual innovation : the connection between leadership and employee's innovative work behavior. Faculty of Economics and Business. University of Amsterdam.

Hadiyati, Ernani. 2010. “Analisis Kualitas Pelayanan dan Pengarunya terhadap Loyalitas Pelanggan (Studi Kasus pada PT. Pos Indonesia (Persero) Kantor Pos Lawang)”. Jurnal Manajemen. Vol. 2, Nomor 2, Juli - Desember 2010. Universitas Gajayana. Malang.

Hermana, Budi. 2006. Mendorong Daya Saing Di Era Informasi Dan Globalisasi: Pemanfaatan Modal Intelektual dan Teknologi Informasi Sebagai Basis Inovasi DiPerusahaan. Universitas Gunadharma.

Larsen, P. \& A. Lewis. 2007. "How Award Winning SMEs Manage The Barriers to Innovation", Journal Creativity and Innovation Management, page: 141-151

Nasution. M.N. 2004. Manajemen Mutu Terpadu. Cetakan Ketiga. Galia Indonesia.

Thomas W Zimmerer, Norman M Scarborough, Kewirausahaan dan Manajemen Usaha Kecil, Salemba empat, 2008. 